\title{
Screening of Five and Six-Membered Nitrogen-Containing Heterocyclic Compounds as New Effective Stimulants of Linum Usitatissimum L. Organogenesis in Vitro
}

Research Article

\author{
Tsygankova $\mathrm{VA}^{1 *}$, Bayer $\mathrm{OO}^{2}$, Andrusevich $\mathrm{Ya} \mathrm{V}^{1}$, Galkin $\mathrm{AP}^{2}$, Brovarets $\mathrm{VS}^{1}$, Yemets $\mathrm{AI}^{2}$, Blume Ya B ${ }^{2}$
}

${ }^{1}$ Department for Chemistry of Bioactive Nitrogen-Containing Heterocyclic Compounds, Institute of Bioorganic Chemistry and Petrochemistry, National Academy of Sciences of Ukraine, Kiev, Ukraine.

${ }^{2}$ Department of Genomics and Molecular Biotechnology, Institute of Food Biotechnology and Genomics, National Academy of Sciences of Ukraine, Kiev, Ukraine.

\section{Abstract}

Linum usitatissimum L. (flax or linseed) is one of the oldest economically important crops used in biotechnology as a source for bioactive compounds. Flax fiber and seed have industrial significance as a source of cellulosic fiber for textile and paper industry and seed oil for pharmaceutical, cosmetic and food industry. The elaboration of new effective techniques for in vitro regeneration of Linum usitatissimum $\mathrm{L}$. is very actual problem today. The influence of low molecular weight five and sixmembered nitrogen-containing heterocyclic compounds on organogenesis of Linum usitatissimum L. cultivar heavenly in vitro has been studied. It was found that heterocyclic compounds derivatives pyridine, pyrimidine, pyrazole and isoflavones revealed high stimulating effect on direct shoot organogenesis of Linum usitatissimum $\mathrm{L}$. in vitro. The maximal shoot regeneration frequency was obtained on the MS media containing heterocyclic compounds at the concentration $10^{-8} \mathrm{M} / 1$ as compared to lower regeneration frequency obtained on the control MS medium containing $1 \mathrm{mg} / \mathrm{l} \mathrm{BAP}$ and $0.05 \mathrm{mg} / \mathrm{l} \mathrm{NAA}$. The maximal index of explants with regeneration (in \%) that exceeded almost twice the same index in control MS medium was obtained on the MS medium containing heterocyclic compound derivative of isoflavones. At the same time, the index of explants with regeneration (in \%) that exceeded one and a half times the same index in control MS medium and the maximal index of shoots elongated more than $1 \mathrm{~cm}$ (in \%) that exceeded almost twice the same index in control MS medium were obtained on the MS media containing heterocyclic compounds derivatives of pyridine, pyrimidine and pyrazole. The current study confirms perspective of using of low molecular weight five and six-membered nitrogen-containing heterocyclic compounds at the concentration $10^{-8} \mathrm{M} / 1$ of the MS medium as new effective substitutes of traditional growth regulators auxin NAA and cytokinin BAP for regeneration of Linum usitatissimum $\mathrm{L}$. cultivar heavenly in vitro.

Keywords: Plant Growth Regulators, MS Medium, NAA, BAP, Nitrogen-Containing Heterocyclic Compounds, Pyridine, Pyrimidine, Pyrazole, Isoflavones, Linum usitatissimum L, Organogenesis in Vitro.

\section{Introduction}

An actual problem for the successful development of plant biotechnology is elaboration of new effective plant growth regulators to improve technology of introduction to in vitro culture of different plant species with low morphogenetic potential, to produce virus-free and pathogen-free lines of plants, to improve techniques of microclonal breeding of plants, to increase synthesis of biologically active compounds and secondary metabolites in the isolated tissue cultures of agricultural and medicinal plants [1-4]. Today, the traditionally known synthetic and natural plant growth regulators with auxin and cytokinin activity such as IAA,
NAA, IBA, 2,4-D, 2,4,5-T, Zeatin, Kinetin, 2iP, BA, BAP, BPA [511] and new plant growth regulators such as BSAA (3-(benzo[b] selenienyl)acetic acid), 5,6-Cl $-\mathrm{IAA}-\mathrm{Me}$ (5,6-dichloroindole-3-acetic acid methylester) [12,13], TDS (thidiazuron) [13-18], as well as natural bioregulators [19-26] are widely used in the biotechnological practice for cultivation of isolated plant tissues and organs and microclonal propagation in vitro of medicinal and agricultural plants. Therefore, the elaboration of new plant growth regulators of synthetic or natural origin as effective substitutes of traditional regulators for practical using in the plant biotechnology is very important and urgent task.

\section{*Corresponding Author:}

Victoria Anatolyivna Tsygankova, ScD,

Department for Chemistry of Bioactive Nitrogen-Containing Heterocyclic Compounds, Institute of Bioorganic Chemistry and Petrochemistry,

National Academy of Sciences of Ukraine, 1, Murmanskaya Str., Kyiv, 02160,Ukraine.

E-mail: vTsygankova@ukr.net

Received: December 1, 2015

Accepted: April 11, 2016

Published: April 22, 2016

Citation: Tsygankova VA, et al. (2016) Screening of five and six-membered nitrogen-containing heterocyclic compounds as new effective stimulants of Linum usitatissimum L.organogenesis in vitro. Int J Med Biotechnol Genetics S2:001, 1-9. doi: http://dx.doi.org/10.19070/2379-1020-SI02001

Copyright: Tsygankova VA ${ }^{\circ}$ 2016. This is an open-access article distributed under the terms of the Creative Commons Attribution License, which permits unrestricted use, distribution and reproduction in any medium, provided the original author and source are credited. 
At the Institute of Bioorganic Chemistry and Petrochemistry of NAS of Ukraine together with the National Enterprise Interdepartmental Science and Technology Center "Agrobiotech" of NAS and MES of Ukraine the several new ecologically safe plant growth regulators of synthetic origin: Ivin and natural origin: Emistim, Poteitin, Zeastimulin, Charkor, Biolan, Biogen, Radostim, Radostim-super, Regoplant and Stimpo that accelerate plant growth, increase yield crop of vegetables, grains, legumes and fruit crops, as well increase plant immune protection against pathogenic and parasitic organisms were created [27-31]. Our previous studies have shown the possibility of using of new synthetic and natural compounds in the isolated tissue cultures of agricultural and medicinal plants to induce morphogenetic processes and increase the synthesis of secondary metabolites [32-34].

Over the last years the another classes of chemical compounds - functionally substituted of low molecular weight five and sixmembered nitrogen-containing heterocyclic compounds were also synthesized at the Institute of Bioorganic Chemistry and Petrochemistry of NAS of Ukraine. Most of them showed antiradical, antioxidant, antitumor, antidepressant, antimicrobial and antiviral activity and could potentially be used as medical drugs for treatment of cancer, immune, cardiovascular, nervous, viral, infectious and other diseases [35-42]. The another strategic focus of our researches is study the influence of low molecular weight heterocyclic compounds derivatives of classes pyridine, pyrimidine, pyrazole and isoflavones on the plant growth and development with the prospect of their using as effective substitutes of traditional plant growth regulators in the biotechnological practice. In favor of target area of our researches witness numerous studies conducted by another authors [43-53].

Linum usitatissimum L. (flax or linseed) is one of the oldest economically important crops that are widely used in biotechnology [54-60]. Linum usitatissimum L. belongs to Linaceae family which consists of more than 300 species mainly known as ornamental plants, but only one species Linum usitatissimum $L$. has a practical importance [55]. Flax fiber and seed have industrial significance as a source of cellulosic fiber for textile and paper industry and seed oil for pharmaceutical, cosmetic and food industry [56, 57]. Flax seed contains various bioactive compounds, the major components include: $41 \%$ fat, $20-31 \%$ protein, $28 \%$ total dietary fiber, $7.7 \%$ moisture, and $3.4 \%$ ash, the minor components include: cyanogenic glycosides, phytic acid, phenolics, trypsin inhibitor, linatine, lignans (phytoestrogens), minerals, vitamins, cadmium, selenium and cyclolinopeptides (CLs) [57, 58]. The essential amino acids such as arginine, aspartic acid, and glutamic acid are the major protein components of the flax seed $[57,58]$. The flax seed oil is an important source of omega-3 fatty acid - alinolenic acid (ALA) which accounts for more than $50 \%$ of fatty acid content of oil [56-59]. The major components of flax seed oil are triacylglycerides which include a mixture of the fatty acids: linolenic $(52 \%)$, linoleic $(17 \%)$, oleic $(20 \%)$, palmitic $(6 \%)$, and stearic $(4 \%)$ acids, the minor lipids and lipid soluble compounds include: monoacylglycerides, diacylglycerides, tocopherols, sterols sterol-esters, phospholipids, waxes, CLs, free fatty acids (FFAs), carotenoids, chlorophyll, and other compounds [57]. Today linseed oil is commonly used in clinical practice for prevention and treatment of cardiovascular disease because it has antioxidant effect and decreases blood total plasma cholesterol, triglyceride (TG), and low-density lipoprotein (LDL) cholesterol without a significant decrease in high-density lipoprotein (HDL) cholesterol
[56-58]. Moreover, another beneficial effect of flax seed oil is due to the presence ALA component which takes part in the biosynthesis of hormone-like eicosanoids that regulate inflammation and immune function in higher animals [57]. The widespread use of dietary food supplemented with flax seed oil omega-3 fatty acid and flax seed lignan secoisolariciresinol diglucoside (SDG) prevents different diseases such as cancer, arthritis, atherosclerosis, diabetes, inflammatory diseases, depression, heart disease, hypertension, memory problems, weight gain, some allergies, kidney disorders and lupus nephritis [56, 60].

Because of using Linum usitatissimum $\mathrm{L}$. in the biotechnology as an important source for bioactive compounds, numerous studies devoted to elaboration of effective techniques for in vitro regeneration of this plant have been conducted for many years [54, 55, 61-66]. Nevertheless, the elaboration of new efficient methods for in vitro cultivation and regeneration of this plant is very actual problem today. Based on the mentioned, the considerable theoretical and practical interest is study the possibility of using of new low molecular weight five and six-membered nitrogencontaining heterocyclic compounds synthesized in the Institute of Bioorganic Chemistry and Petrochemistry of NAS of Ukraine for stimulation of organogenesis of Linum usitatissimum L. in vitro conditions.

The objective of this work is study of impact of low molecularweight synthetic five and six-membered nitrogen-containing heterocyclic compounds derivatives of pyridine, pyrimidine, pyrazole and isoflavones on shoot organogenesis of Linum usitatissimum $\mathrm{L}$. cultivar heavenly in vitro.

\section{Materials and Methods}

\section{Chemicals}

In our experiments the biological activity of synthetic low molecular weight five and six-membered nitrogen-containing heterocyclic compounds derivatives of pyridine $((1 \mathrm{H}-$ pyrrolo[2,3-c]pyridin-3-yl)-acetic acid), pyrimidine(6-Methanesulfonyl-imidazo[1,2-a]pyrimidine-5-ylamine), pyrazole (5-hydrazino-1-phenyl-1H-pyrazole-4-carbohydrazide and 3-Ethyl-7-methyl-3, 7-dihydropyrazole [3,4-d] [1,2,3]triazin-4-one) and isoflavones (5-hydroxy-7-methoxy-8-(methoxymethyl)-3-(4methoxyphenyl)-4H-chromen-4-one) was studied. These compounds were synthesized at the Department for Chemistry of Bioactive Nitrogen-Containing Heterocyclic Compounds of Institute of Bioorganic Chemistry and Petrochemistry of NAS of Ukraine. The methods of synthesis of these heterocyclic compounds are described in the works [67-71].

The biological activity of chemical compounds was compared with activity of growth regulators: auxin NAA (Naphthalen-1-yl-acetic acid) and cytokinin BAP (N-(Phenylmethyl)-1H-purin-6-amine or 6-Benzylaminopurine). Chemical structures and relative molecular mass of growth regulators NAA, BAP and heterocyclic compounds used for bioassays are shown on the Figure1.

\section{Plant Growing Conditions}

To study impact of synthetic heterocyclic compounds on shoot organogenesis in vitro seeds of Linum usitatissimum L. cultivar 
Figure 1. Chemical structures of synthetic compounds used for bioassays.

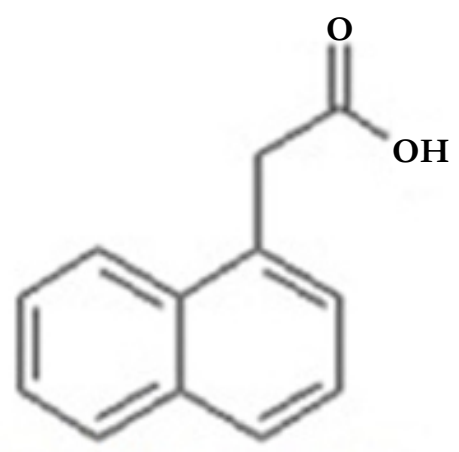

Naphthalen-1-yl-acetic acid; Molar mass $=186.21 \mathrm{~g} / \mathrm{mol} ;\left(10^{-8} \mathrm{M} /\right.$ $1=0,0018621 \mathrm{mg} / \mathrm{l})$

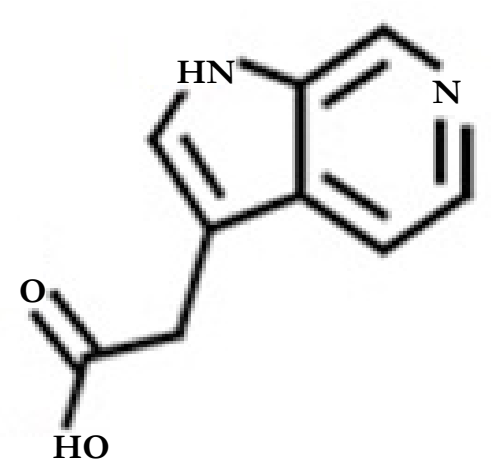

H-pyrrolo[2,3-c]pyridin-3-yl-acetic acid; Molar mass $=176.175 \mathrm{~g} / \mathrm{mol}$; $\left(10^{-8} \mathrm{M} / \mathrm{l}=0,00176175 \mathrm{mg} / \mathrm{l}\right)$
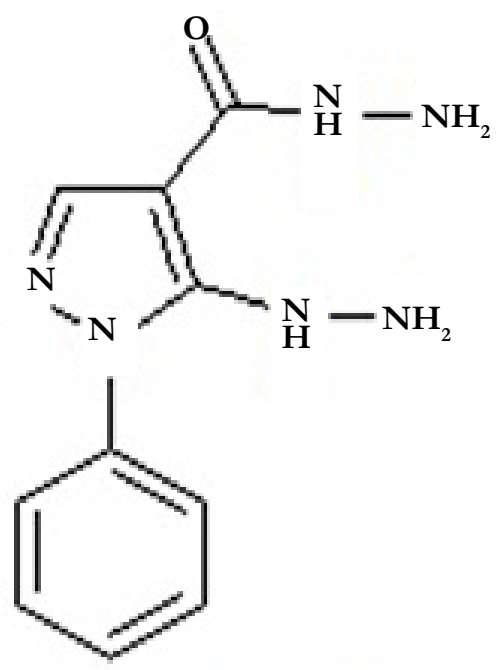

5-hydrazino-1-phenyl-1H-pyrazole-4-carbohydrazide; Molar mass $=232.25 \mathrm{~g} / \mathrm{mol} ;\left(10^{-8} \mathrm{M} /\right.$ $1=0,0023225 \mathrm{mg} / \mathrm{l})$<smiles>c1ccc(CNc2ncnc3nc[nH]c23)cc1</smiles>

N-(Phenylmethyl)-1H-purin-6-amine; Molar mass $=225.249 \mathrm{~g} / \mathrm{mol} ;\left(10^{-8} \mathrm{M} /\right.$ $1=0,00225249 \mathrm{mg} / \mathrm{l})$

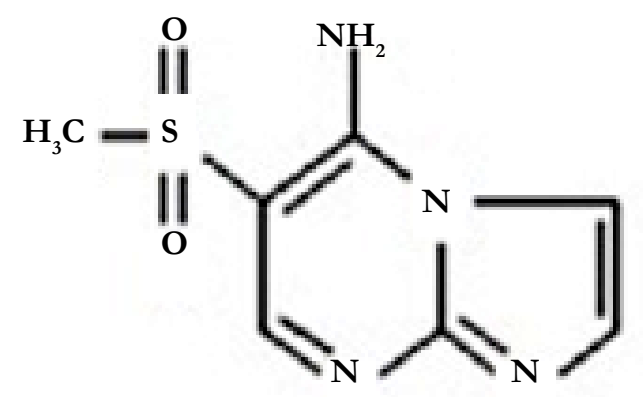

6-Methanesulfonyl-imidazo[1,2-a]pyrimidine5 -ylamine; Molar mass $=212.23 \mathrm{~g} / \mathrm{mol} ;\left(10^{-8} \mathrm{M} /\right.$ $1=0,0021223 \mathrm{mg} / \mathrm{l}$ )<smiles>CCn1nnc2[nH]ncc2c1=O</smiles>

3-Ethyl-7-methyl-3,7-dihydropyrazole [3,4-d] $[1,2,3]$ triazin-4-one; Molar mass $=179.18 \mathrm{~g} / \mathrm{mol}$; $\left(10^{-8} \mathrm{M} / \mathrm{l}=0,0017918 \mathrm{mg} / \mathrm{l}\right)$<smiles>COCc1c(OC)cc(O)c2c(=O)c(-c3ccccc3OC)coc12</smiles> 
heavenly were initially sterilized in the laminar box using magnetic stirrer with $70 \%$ ethanol solution for $1 \mathrm{~min}$ and in $5 \%$ sodium hypochlorite solution for $6 \mathrm{~min}$ at the temperature $20-22^{\circ} \mathrm{C}$. The surface of sterilized seeds was washed three times with sterile distilled water for $10 \mathrm{~min}$. Then, the seeds were placed in Petri dishes (9.0 $\mathrm{cm}$ in diameter) each containing $25 \mathrm{ml} \mathrm{MS}$ (Murashige and Skoog) basal medium [72] supplemented with half-strength MS macro- and micro salts, $20 \mathrm{~g} / 1$ sucrose and $8 \mathrm{~g} / 1$ agar, then the media were adjusted to $\mathrm{pH}$ 5,7-5,8 before autoclaving. Then Petri dishes were placed in the box for plant cultivation in which seedlings were grown for 5-6 days at the 16/8 h light/dark conditions, the temperature was $24-25^{\circ} \mathrm{C}$, light intensity was 3000 lux and air humidity was $60-80 \%$. After 5-6 days of seed germination the seedlings with open cotyledons were formed.

With the aim to prepare explants for in vitro experiments the segments of hypocotyl of 7 th days seedlings were aseptically cut into segments (2-3 mm length) and placed horizontally in the Petri dishes (each containing 25 pcs) on the surface of the nutrient MS medium. Three Petri dishes were used in the each variant. Culture media for explant cultivation were supplemented with macro- and micro salts contained in MS basal medium [72], $20 \mathrm{~g} / 1$ sucrose, $8 \mathrm{~g} / \mathrm{l}$ agar and each chemical low molecular weight heterocyclic compound at the concentration of $10^{-8} \mathrm{M} / 1$ of MS medium.

MS basal medium containing $1 \mathrm{mg} / 1 \mathrm{BAP}$ and $0.05 \mathrm{mg} / 1 \mathrm{NAA}$ was used as a control sample for shoot regeneration of flax explants. The efficiency of regeneration was determined according to: a) the number of explants with regeneration (in $\%$ ) and b) the number of shoots longer than $1 \mathrm{~cm}$ (in \%) obtained in the experimental samples relative to the control. The obtained shoots were rooted on hormone-free MS medium containing half-strength MS macro- and micro salts and vitamins, $10 \mathrm{~g} / 1$ sucrose and $7 \mathrm{~g} / \mathrm{l}$ agar.

All the experiments were performed in three replicates. Statistical analysis of the data was performed using dispersive Student's- $t$ test with the level of significance at $\mathrm{P}=0.05$, the values are mean $\pm \mathrm{SD}[73]$.

\section{Results}

The inducing effect of low molecular heterocyclic compounds derivatives of pyridine ((1H-pyrrolo[2,3-c]pyridin-3-yl)-acetic acid), pyrimidine (6-Methanesulfonyl-imidazo[1,2-a]pyrimidine5-ylamine), pyrazole (5-hydrazino-1-phenyl-1H-pyrazole-4-carbohydrazide and 3-Ethyl-7-methyl-3,7-dihydropyrazole[3,4-d] $[1,2,3]$ triazin-4-one) and isoflavones (5-hydroxy-7-methoxy-8(methoxymethyl)-3-(4-methoxyphenyl)-4H-chromen-4-one) as well as growth regulators NAA and BAP on shoot organogenesis in the isolated tissue cultures of Linum usitatissimum L. cultivar heavenly was studied. It was found that heterocyclic compounds at the concentration $10^{-8} \mathrm{M} / \mathrm{l}$ of $\mathrm{MS}$ medium revealed maximal stimulating effect on shoot regeneration as compared to lower effect of $1 \mathrm{mg} / 1 \mathrm{BAP}$ and $0.05 \mathrm{mg} / 1 \mathrm{NAA}$ supplemented into control MS medium (Figure 2 and Figure 3).

The maximal index of explants with regeneration (in \%) that exceeded almost twice the control index was obtained on the MS medium containing heterocyclic compound derivative of isoflavones (5-hydroxy-7-methoxy-8-(methoxymethyl)-3-(4-methoxyphenyl)$4 \mathrm{H}$-chromen-4-one). At the same time the activity of this compound according to index of shoots elongated more than $1 \mathrm{~cm}$ (in \%) was lower as compared with activity of heterocyclic compounds derivative of pyridine ((1H-pyrrolo[2,3-c]pyridin-3-yl)acetic acid) and pyrimidine (6-Methanesulfonyl-imidazo[1,2-a] pyrimidine-5-ylamine) and was similar to the activity of pyrazole (5-hydrazino-1-phenyl-1H-pyrazole-4-carbohydrazide) (Figure 4).

According to index of explants with regeneration (in \%) the chemical compounds derivative of pyrimidine (6-Methanesulfonyl-imidazo[1,2-a]pyrimidine-5-ylamine),pyrazole(5-hydrazino-1-phenyl-1H-pyrazole-4-carbohydrazide) and pyridine ((1H-pyrrolo[2,3-c]pyridin-3-yl)-acetic acid) showed activity that exceeded one and a half times activity of growth regulators NAA and BAP containing in the control MS medium (Figure 4).

It was observed that according to index of shoots elongated more than $1 \mathrm{~cm}$ (in \%) the activity of heterocyclic compounds derivative of pyrimidine (6-Methanesulfonyl-imidazo[1,2-a]pyrimidine5-ylamine), pyrazole (5-hydrazino-1-phenyl-1H-pyrazole-4-carbohydrazide) and pyridine ((1H-pyrrolo[2,3-c]pyridin-3-yl)-acetic acid) exceeded almost twice activity of growth regulators NAA and BAP supplemented into control MS medium (Figure 4).

At the same the activity of heterocyclic compound derivative of pyrazole (3-Ethyl-7-methyl-3,7-dihydropyrazole[3,4-d][1,2,3] triazin-4-one) according to index of explants with regeneration (in \%) and index of shoots elongated more than $1 \mathrm{~cm}$ (in \%) was less as compared with activity above mentioned heterocyclic compounds but somewhat exceeded activity of growth regulators auxin NAA and cytokinin BAP (Figure 4).

The obtained shoots were rooted on the hormone-free MS medium elaborated in our previous work [74] (Figure 5).

Thus, the results of this work confirm that synthetic low molecular weight five and six-membered nitrogen-containing heterocyclic compounds derivatives of pyridine, pyrimidine, pyrazole and isoflavones showed high stimulating activity on direct shoot organogenesis in the isolated tissue culture of Linum usitatissimum L. cultivar heavenly in vitro which exceeds the activity of growth regulators auxin NAA and cytokinin BAP.

\section{Discussion}

Data of our previous researches and numerous data of other authors witness that regeneration ability of flax (Linum usitatissimum L.) is under the influence of various types of growth regulators and their different concentrations in the culture media as well as origin of the plant explants [55, 62-66, 75-78].

For example in our previous work [65] we studied morphogenetic responses of 12 fibre flax genotypes (Linum usitatissimum L.) on two hormone combinations in different culture media: MS-BN containing $1 \mathrm{mg} / 1 \mathrm{BAP}$ and $0.05 \mathrm{mg} / 1 \mathrm{NAA}$ and MS-DZ containing $0.4 \mathrm{mg} / 12$,4-D and $1.6 \mathrm{mg} / 1$ Zeatin. It was shown that light green compact calli and shoot proliferation were obtained from hypocotyl explants on medium MS-BN containing $1 \mathrm{mg} / \mathrm{l} \mathrm{BAP}$ and $0.05 \mathrm{mg} / 1 \mathrm{NAA}$.

Similar studies were conducted in the works $[55,66,74-78]$. The inducing effect of various concentrations of growth regulators NAA, BAP, TDZ and 2iP added into basal MS medium on the formation of callus, shoot and root from hypocotyl explants of 
Figure 2. Impact of growth regulators NAA and BAP (control) and synthetic five and six-membered nitrogen-containing heterocyclic compounds (experiment) on shoot organogenesis of Linum usitatissimum $\mathrm{L}$. cultivar heavenly in vitro.
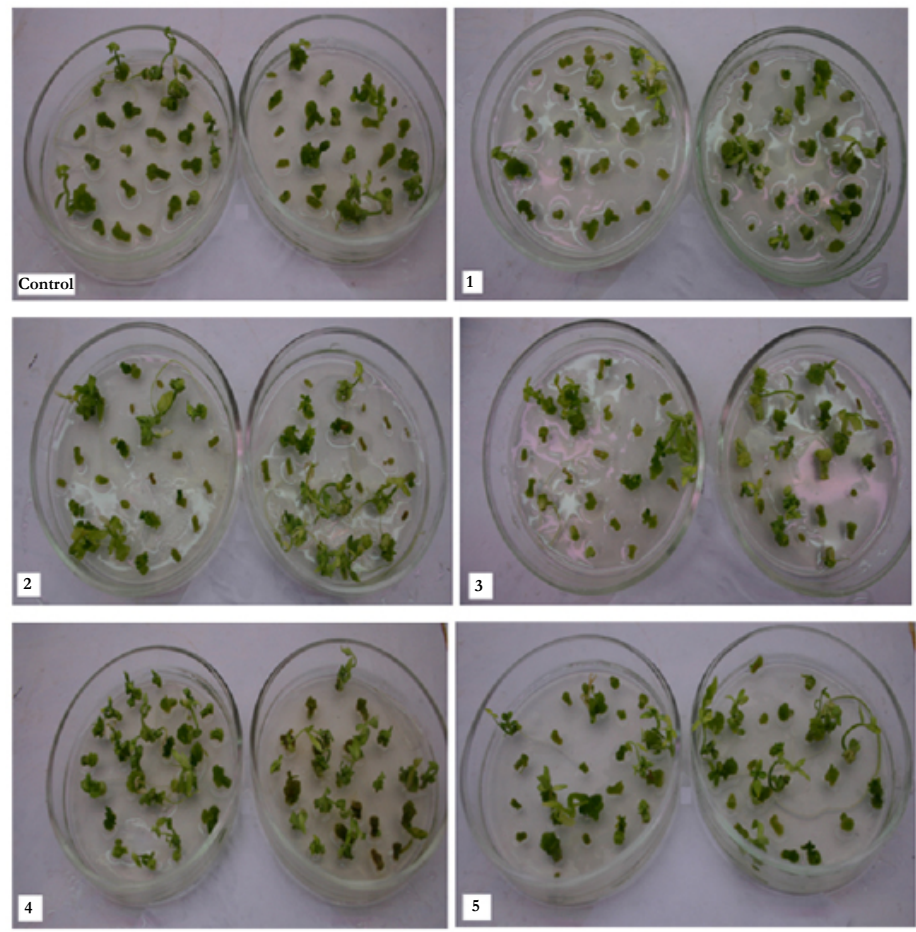

Control - NAA+BAP,

1. 6-Methanesulfonyl-imidazo[1,2-a]pyrimidine-5-ylamine, 2. 5-hydrazino-1-phenyl-1H-pyrazole-4-carbohydrazide,

3. 3-Ethyl-7-methyl-3,7-dihydropyrazole[3,4-d] [1,2,3]triazin-4-one, 4. 5-hydroxy-7-methoxy-8-(methoxymethyl)-3-(4-methoxyphenyl)-4H-chromen-4-one, 5. (1H-pyrrolo[2,3-c]pyridin-3-yl)-acetic acid

Figure 3. Average number of explants with regeneration and number of shoot longer than $1 \mathrm{~cm}$ obtained per one Petri dish.

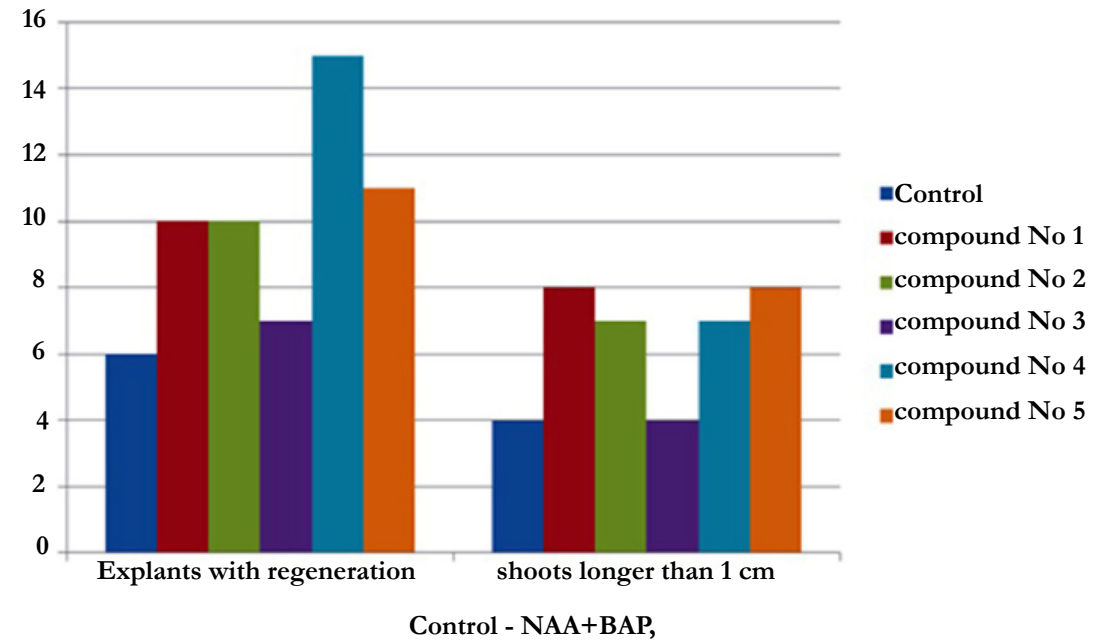

1. 6-Methanesulfonyl-imidazo[1,2-a]pyrimidine-5-ylamine, 2. 5-hydrazino-1-phenyl-1H-pyrazole-4-carbohydrazide,

3. 3-Ethyl-7-methyl-3,7-dihydropyrazole[3,4-d][1,2,3]triazin-4-one, 4. 5-hydroxy-7-methoxy-8-(methoxymethyl)-3-(4-methoxyphenyl)-4H-chromen-4-one, 5. (1H-pyrrolo[2,3-c]pyridin-3-yl)-acetic acid

Linum usitatissimum L. was studied [55]. It was found that highest regeneration effectiveness was observed on the MS media supplemented with $1 \mathrm{mg} / \mathrm{lBAP}$.

The effect of different concentrations and combinations of growth regulators BAP, NAA and TDZ on shoot regeneration from hypocotyl explants of three flax cultivars (Linum usitatissimum L.) was investigated [66]. The best results of shoot regeneration (up to $70.0-100 \%$ ) were obtained on the MS medium containing $1 \mathrm{mg} / 1 \mathrm{BAP}$ and $0.02 \mathrm{mg} / 1 \mathrm{NAA}$, at the same time increase of
TDZ concentrations above $1 \mathrm{mg} / \mathrm{l}$ significantly reduced the shoot regeneration frequency due toxic effect of TDZ on explant (resulting in tissue necrosis and explant death).

In the work [75] the most effective shoot multiplication (that was about twice higher in the light-grown cultures than those in the darkness) from hypocotyl explants of oil flax (Linum usitatissimum L., cv. 'Szafir') was obtained on MS medium containing $0.05 \mathrm{mg} / 1$ 2,4-D and $1 \mathrm{mg} / \mathrm{l} \mathrm{BA}$. 
Figure 4. Efficiency of regeneration: A) the number of explants with regeneration (in \%) and B) the number of shoot longer than $1 \mathrm{~cm}$ (in \%) obtained in the experimental samples relative to the control.

A
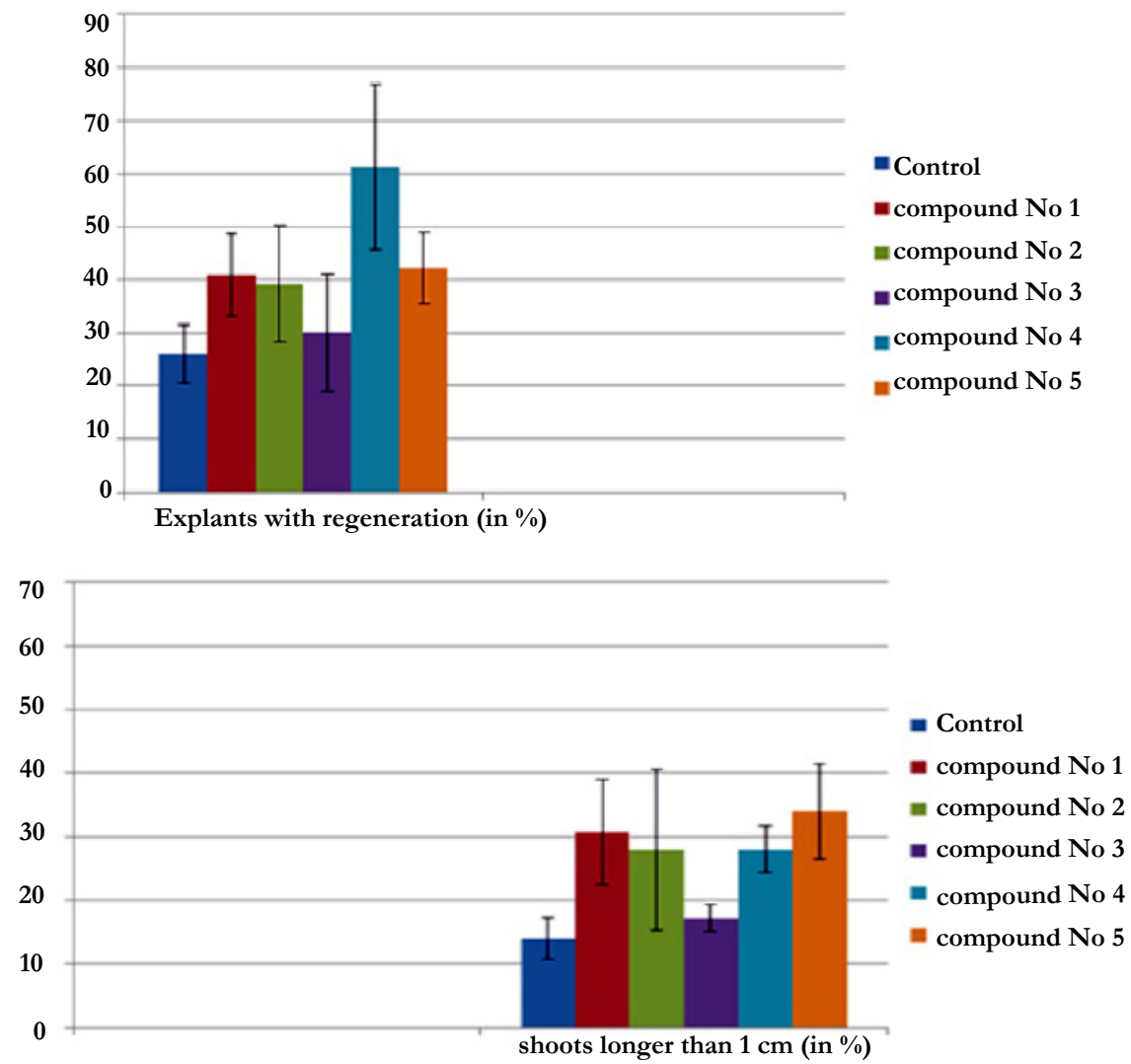

Control - NAA+BAP,

1. 6-Methanesulfonyl-imidazo[1,2-a]pyrimidine-5-ylamine, 2. 5-hydrazino-1-phenyl-1H-pyrazole-4-carbohydrazide,

3. 3-Ethyl-7-methyl-3,7-dihydropyrazole[3,4-d][1,2,3] triazin-4-one, 4. 5-hydroxy-7-methoxy-8-(methoxymethyl)-3-(4-methoxyphenyl)-4H-chromen-4-one, 5. (1H-pyrrolo[2,3-c]pyridin-3-yl)-acetic acid

Figure 5. Rooting of shoots on the hormone-free MS medium.

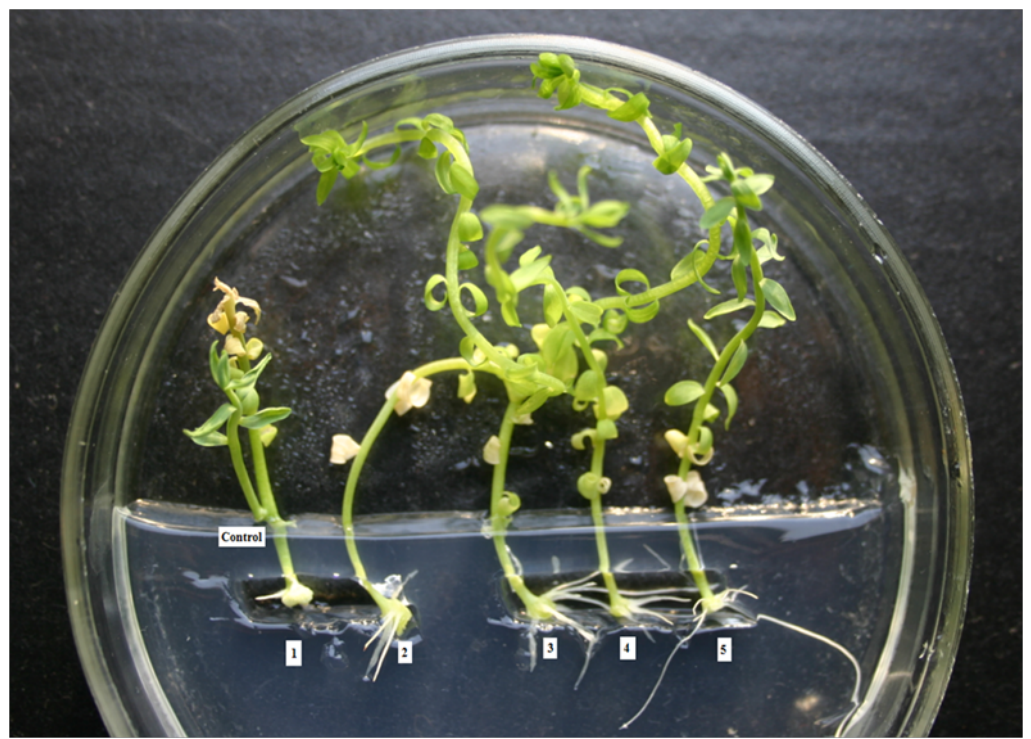

Control - Shoots previously obtained on the MS medium supplemented with NAA+BAP;

1. Shoots previously obtained on the MS medium supplemented with 6-Methanesulfonyl-imidazo[1,2- $a$ ]pyrimidine-5-ylamine;

2. Shoots previously obtained on the MS medium supplemented with 5-hydrazino-1-phenyl-1H-pyrazole-4-carbohydrazide;

3. Shoots previously obtained on the MS medium supplemented with 3-Ethyl-7-methyl-3,7-dihydropyrazole[3,4-d][1,2,3]triazin-4-one;

4. Shoots previously obtained on the MS medium supplemented with 5-hydroxy-7-methoxy-8-(methoxymethyl)-3-(4-methoxyphenyl)-4H-chromen-4-one;

5. Shoots previously obtained on the MS medium supplemented with (1H-pyrrolo[2,3-c]pyridin-3-yl)-acetic acid 
The effect of various concentrations and combinations of growth regulators BAP, GA3, Kin, IBA on shoot regeneration from shoot tip and nodal segment of linseed (Linum usitatissimum L., cv. neela) was studied [76]. It was shown that multiple shoot induction was achieved on the MS medium supplemented with $2.0 \mathrm{mg} / \mathrm{l} \mathrm{BAP}$, at the same time shoots were rooted most effectively in MS medium supplemented with $0.5 \mathrm{mg} / 1 \mathrm{NAA}$.

In the work [77] an optimal composition of different culture media: Sh2 medium supplemented with $1.0 \mathrm{mg} / 1 \mathrm{BAP}$ and $0.05 \mathrm{mg} / 1$ NAA, Sh3 medium supplemented with $0.1 \mathrm{mg} / 1 \mathrm{BAP}, 0.5 \mathrm{mg} / 1$ NAA and $0.3 \mathrm{mg} / 1 \mathrm{IAA}$ as well as Sh50 medium supplemented with $0.02 \mathrm{mg} / 1 \mathrm{BAP}$ and $0.001 \mathrm{mg} / 1 \mathrm{NAA}$ were elaborated for the efficient production of flax plants regenerated from somatic explants from hypocotyls, cotyledons, leaves, stems and roots as well as plants regenerated from anther and microspore cells. It was found that medium supplemented with two carbon sources (2.5\% sucrose and $2.5 \%$ glucose) was most effective for callus induction, whereas medium supplemented with sucrose at lower concentration $(2 \%)$ was effective for shoots. Root formation was most efficient on the medium supplemented with $1 \%$ sucrose and reduced $(50 \%)$ mineral concentration.

The effect of growth regulator combinations $(1.0 \mathrm{mg} / 1$ kinetin and $0.1 \mathrm{mg} / 1 \mathrm{IAA}, 1.0 \mathrm{mg} / 1 \mathrm{BAP}$ and $0.05 \mathrm{mg} / 1 \mathrm{NAA}, 2.0 \mathrm{mg} / 1$ $2 \mathrm{iP}$ or $1.0 \mathrm{mg} / \mathrm{l}$ kinetin) on adventitious shoot organogenesis from hypocotyl-derived and stem segment-derived callus of different linseed cultivars was studied [78]. Obtained results showed that maximum shoot regeneration frequency was obtained from hypocotyl-derived four week-old callus in all cultivars tested on combined MSB5 media, supplemented with $2.0 \mathrm{mg} / 1$ 2iP.

Data obtained in this work testify that the low molecular weightfive and six-membered nitrogen-containing heterocyclic compounds revealed high stimulating activity on direct shoot organogenesis of Linum usitatissimum L. cultivar heavenly in vitro. These results confirm possibility of using of low molecular weight heterocyclic compounds as new effective substitutes of growth regulators auxin NAA and cytokinin BAP for micropropagation of Linum usitatissimum $\mathrm{L}$. cultivar heavenly in vitro.

\section{Conclusion}

Impact of low molecular weight five and six-membered nitrogen-containing heterocyclic compounds derivatives of pyridine, pyrimidine, pyrazole and isoflavones on shoot organogenesis of flax (Linum usitatissimum L.) cultivar heavenly in vitro was studied. According to indexes of shoot organogenesis it was found that heterocyclic compounds at the concentration $10^{-8} \mathrm{M} / 1$ showed similar to auxin and cytokinin activity which exceeds almost one and a half - twice the activity of growth regulators auxin NAA and BAP. Obtained data confirm possibility of using of low molecular weight five and six-membered nitrogen-containing heterocyclic compounds as new efficient plant growth regulators in the biotechnological practice.

\section{References}

[1]. Bhojwani SS, Razdan MK (1996) Plant Tissue Culture: Theory and Practice. (1st edtn), Elsevier Science. 767.

[2]. Kayser O, Quax WJ (2007) Medicinal Plant Biotechnology. From Basic Research to Industrial Applications. WILEY-VCH Verlag GmbH \& Co.
KGaA, Weinheim. 604.

[3]. George EF, Hall MA, De Klerk GJ (2008) Plant Propagation by Tissue Culture. The Background. 1: 501.

[4]. Smith RH (2013) Plant Tissue Culture Techniques and Experiments. (3rd edtn). Elsevier Inc. 188.

[5]. Jiménez VM (2005) Involvement of plant hormones and plant growth regulators on in vitro somatic embryogenesis. Plant Growth Regulation. 47: 91 110.

[6]. Debnath SC (2006) Influence of propagation method and indole-3-butyric acid on growth and development of in vitro- and ex vitro-derived lingonberry plants. Can J Plant Sci 86(1): 235-243.

[7]. Arya A, Kumar S, Kasana MS (2012) Effect Of Plant Growth Regulators And $\mathrm{pH}$ of Medium on In Vitro Regeneration of Pinus Roxburghii Sarg. Indian Journal of Fundamental and Applied Life Sciences 2(4): 66-75.

[8]. Otroshy M, Khalili Z, Ebrahimi MA, Nekoui MK, Moradi K (2013) Effect of growth regulators and explants on plant regeneration of Solanum lycopersicum L. var. cerasiforme.Russ. Agricul. Sci.39, Issue 3: 226-235.

[9]. Rawat JM, Rawat B, Chandra A, Nautiyal S (2013) Influence of plant growth regulators on indirect shoot organogenesis and secondary metabolite production in Aconitum violaceum Jacq. African Journal of Biotechnology. 12(44): 6287-6293.

[10]. Shimelis D, Bantte K, Feyissa T (2015) Interaction Effect of Indole- 3-Butyric Acid and $\alpha$-Naphthalene Acetic Acid on In Vitro Rooting of Two Sugarcane (Saccharum officinarum) Genotypes. Adv Crop Sci Tech S1: 001.

[11]. Koné M, Koné T, Kouakou HT, Konaté S, Ochatt JS (2013) Plant regeneration via direct shoot organogenesis from cotyledon explants of Bambara groundnut, Vigna subterranea (L.) Verdc. Biotechnol Agron Soc Environ 17(4): 584-592.

[12]. Pan R, Tian X (1999) Comparative effect of IBA, BSAA and 5,6-Cl2-IAAMe on the rooting of hypocotylin mung bean. Plant Growth Regul 28: 91 98 .

[13]. Langhansova L, Marsik P, Vanek T (2012) Regulation of tissue differentiation by plant growth regulators on tTCLs of Panax ginseng adventitious roots. Industrial Crops and Products. 35: 154-159.

[14]. Jiang B, Yang YG, Guo YM, Guo ZC, Chen YZ (2005) Thidiazuron-induced in Vitro Shoot Organogenesis of the Medicinal Plant Arnebia Euchroma (royle) Johnst. In Vitro Cellular \& Developmental Biology. Plant 41(5): 677-681.

[15]. Mamaghani MS, Assareh MH, Omidi M, Matinizadeh M, Ghamari-Zare A, et al. (2009) The effect of thidiazuron level on in vitro regeneration type and peroxidase profile in Eucalyptus microtheca. Plant Growth Regul 59: 199-205.

[16]. Guo B, Abbasi BH, Zeb A, Xu LL, Wei YH (2011) Thidiazuron: A multi-dimensional plant growth Regulator. African Journal of Biotechnology 10(45): 8984-9000

[17]. Asghar S, Abbas SJ, Wahab F, Khan NH, Ahmad N, et al. (2013) Direct induction of somatic embryogenesis and plant regeneration from cotyledon explants of Myrica rubra Sieb. \& Zucc. African Journal of Agricultural Research 8(2): 216-223.

[18]. Vijaya kumar J, Rathi GS, Bhuvaneshwari SM, Kumari BDR, Castaño E (2014) Thidiazuron-induced shoot organogenesis of Cleome viscosa (L) through cotyledonary explants culture. African Journal of Biotechnology 13(9): 1027-1036.

[19]. Zeljković SB, Parađiković NA, Babić TS, Đurić GD, Oljača RM, et al. (2010) Influence of Biostimulant and Substrate Volume on Root Growth and Development of Scarlet Sage (Salvia Splendens L.) Transplants. Journal of Agricultural Sciences. 55(1): 29-36.

[20]. Parađiković NA, Tkalec MB, Zeljković SB, Vinković TM (2014) Biostimulant Application In Transplants Production Of Allium Sativum L. And Wild Roses (Rosa Canina L.) Fifth International Scientific Agricultural Symposium „Agrosym 2014“: 694-699.

[21]. Tkalec MB, Parađiković NA, Zeljković SB, Vinković TM (2012) Influence of medium on growth and development of wild rose in vitro. International Conference on BioScience: Biotechnology and Biodiversity - Step in the Future. 104-107.

[22]. Kaewduangta W, Reamkatog P (2011) Effect of modification medium on growth development of Dendrobium parishii. American-Eurasian J Agric Environ Sci 11(1): 117-121.

[23]. Shadang R, Dwivedi P, Hegde SN, Ahmed N (2007) Effect of different culture media on seed germination and subsequent in vitro development of protocorms of Hygrochilus parishii (Veith and Rchb.f.) Pfitz (Orchidaceae). Indian Journal of Biotechnology 6: 256-261.

[24]. Vinoth S, Gurusaravanan P, Jayabalan N (2012) Effect of seaweed extracts and plant growth regulators on high-frequency in vitro mass propagation of Lycopersicon esculentum L (tomato) through double cotyledonary nodal explant. J Appl Phycol 24: 1329-1337.

[25]. Satish L, Rameshkumar R, Rathinapriya P, Pandian S, Rency AS, et al. 
(2015) Effect of seaweed liquid extracts and plant growth regulators on in vitro mass propagation of brinjal (Solanum melongena L.) through hypocotyl and leaf disc explants. Journal of Applied Phycology 27(2): 993-1002.

[26]. Kannan TMS, Sownthariya S, Anbazhakan S (2104) In vitro mass propagation of Withania somnifera Dunal using seaweed extract. International Letters of Natural Sciences 24: 8-14.

[27]. Tsygankova VA, Stefanovska TR, Galkin AP, Ponomarenko SP, Blume YaB (2012) Inducing effect of PGRs on small regulatory si/miRNA in resistance to sugar beet cyst nematode. Comm Appl Biol Sci Ghent University (Belgium). 77(4): 779-788.

[28]. Tsygankova VA, Ponomarenko SP, Hrytsaenko ZM (2012) Increase of plant resistance to diseases, pests and stresses with new biostimulants, Acta Horticulturae, Strasburg (France). 1009: 225-233.

[29]. Tsygankova VA, Andrusevich YV, Ponomarenko SP, Galkin AP, Blume YaB (2012) Isolation and Amplification of cDNA from the Conserved Region of the Nematode Heterodera schachtii $8 \mathrm{H} 07$ Gene with a Close Similarity to Its Homolog in Rape Plants. Cytology and Genetics 46(6): 335-341.

[30]. Tsygankova VA, Iutynska GA, Galkin AP, Blume YaB (2014) Impact of New Natural Biostimulants on Increasing Synthesis in Plant Cells of Small Regulatory si/miRNA with High Anti-Nematodic Activity. Internat J Biol 6(1): 48-64.

[31]. Tsygankova VA, Stefanovska TR, Andrusevich YV, Ponomarenko SP, Yemets AI, Grigoryuk IO, Blume YaB(2015) RNAi-Mediated Effect of Biostimulant Regoplant in Protection of Common Horse Chestnut of Aesculus L. Genus Against The Damaging Action of Horse Chestnut Leaf Miner Cameraria ohridella DESCHKA \& DIMIC. Journal of Biology and Nature 4(1): 19-38.

[32]. Tsygankova VA, Blume YaB (1997) Screening and peculiarity of the biological action of synthetic plant growth regulators. Biopolymers and Cell 13(6): 484-492.

[33]. Tsygankova VA, Galkina LA, Synytsa AD (2006) Triamelon - a new effective inductor of organogenesis in plant tissue culture in vitro. Journal of Organic and Pharmaceutical Chemistry 2(14): 78-80.

[34]. Tsygankova VA, Yemets AI, Ponomarenko SP, Matvieieva AN, Chapkevich SE, et al. (2013) Increase in the synthesis of polyfructan in the cultures of chicory "hairy roots" with plant natural growth regulators. Int J BioMedicine 3(2): 139-144

[35]. Shablykin OV, Kucharenko OP, Iakovenko IN, Yarmoluk SM, Brovarets VS (2008) Search for specific protein kinase CK2 inhibitors and vasoactive compounds among 5-amino-1,3-oxazoles derivatives. Ukrainica Bioorganica Acta 1: 28-36.

[36]. Kopernik IM, Blagodatnyj VM, Petrenko OV, Kalashnikova LE, Prokopenko VV, et al. (2011) Study in vitro for antimicrobic activity of new oxazole derivatives and products of its transformations. Ukr Bioorg Acta 2: 57-68.

[37]. Havrylyuk D, Zimenkovsky B, Vasylenko O, Gzella A, Lesyk R (2012) Synthesis of New 4-Thiazolidinone-, Pyrazoline-, and Isatin-Based Conjugates with Promising Antitumor Activity. J Med Chem 55(20): 8630-8641.

[38]. Zelisko N, Atamanyuk D, Vasylenko O, Grellier P, Lesyk R. (2012) Synthesis and antitrypanosonal activity of new 6,6,7-trisubstituted thiopyrano[2,3d]-[1,3]thiazoles. Bioorg Med Chem Lett 22: 7071-7074.

[39]. Havrylyuk D, Zimenkovsky B, Vasylenko A, Day GW, Smee DF, et al. (2013) Synthesis and biological activity evaluation of 5-pyrazoline substituted 4-thiazolidinones. European Journal of Medicinal Chemistry 66: 228237.

[40]. Frasinyuk MS, Mrug GP, Bondarenko SP, Khilya VP, Brovarets VS (2013) Antitumor activity of flavonoid Mannich bases. Ukrainica Bioorganica Acta 2: 3-7

[41]. Bezverkha IS, Panteleimonova TM, Sharabura LB, Frasyniuk MS, Khylia VP (2014) Antidepressant Effect Of Isoflavone 5/09 on Anxious Depression In Male Mice. Problems Aging and Longevity 23(2): 101-112.

[42]. Frasinyuk MS (2015) Synthesis and Aminomethylation of 3-Substituted 6-Hydroxy-1,2-Benzisoxazoles. Chemistry of Heterocyclic Compounds 50(11): 1616-1623.

[43]. Armarego WLF (1967) In The Chemistry of Heterocyclic Compounds, Fused Pyrimidines, Part I:"Quinazolines". Brown, D.J. (Ed.). Vol. 24/1, Interscience Publishers: New York. 529.

[44]. Harris RLN, Huppatz JL, Teitei T (1979) Synthetic Plant Growth Regulators. The Synthesis of C-o-Carboxyphenyl Derivatives of Pyrimidine. Australian Journal of Chemistry 32(3): 669-679.

[45]. Plant Growth Regulators in Agriculture and Horticulture: Their Role and Commercial Uses. (2000). Basra A.S. (Ed). The Haworth Press. Inc., New York. 264.

[46]. Pesticides - Advances in Research and Application: 2013 Edition. (2013). Acton Q.A. (Ed.). Scholarly Editions, Georgia. 862.

[47]. Cansev A, GÜlen H, Zengin MK, Ergin S, Cansev M, et al. (2016) Use Of Pyrimidines In Stimulation Of Plant Growth And Development And Enhancement Of Stress Tolerance. Patent 20160000075.
[48]. Scriven EFV, Murugan R (2005) Pyridine and Pyridine Derivatives. KirkOthmer Encyclopedia of Chemical Technology. John Wiley \& Sons, Inc. 20: 1-53.

[49]. Dai H, Yu HB, Liu JB, Li YQ, Qin X, et al. (2009) Synthesis and bioactivities of novel trifluoromethylated pyrazole oxime ether derivatives containing a pyridyl moiety. ARKIVOC. (vii): 126-142.

[50]. Corsi C, Wendeborn SV, Bobbio C, Kessabi J, Schneiter P, et al. (2011) Isothiazole and pyrazole derivatives for use as plant growth regulators. Patent EP2358699A1.

[51]. Dai H, Li YQ, Du D, Qin X, Zhang X, et al. (2008) Synthesis and biological activities of novel pyrazole oxime derivatives containing a 2-chloro-5-thiazolyl moiety. J Agric Food Chem 56(22): 10805-10810.

[52]. Isoflavones: Chemistry, Analysis, Function and Effects (2013) Preedy V.R. (Ed). Cambridge, UK.

[53]. Fang Tian F, Jia T, Yu B (2014) Physiological regulation of seed soaking with soybean isoflavones on drought tolerance of Glycine max and Glycine soja. Plant Growth Regulation. 74(3): 229-237.

[54]. McHughen A (1990) Flax (Linum usitatissimum L.): In Vitro Studies. In Chapter Legumes and Oilseed Crops I. Biotechnology in Agriculture and Forestry 10: 502-514.

[55]. Janowicz J, Niemann J, Wojciechowski A (2012) The effect of growth regulators on the regeneration ability of flax (Linum usitatissimum L.) hypocotyl explants in in vitro culture. Bio Technologia 93(2): 135-138.

[56]. Jhala AJ, Hall LM (2010) Flax (Linum usitatissimum L.): Current Uses and Future Applications. Australian Journal of basic and Applied Sciences. 4(9): 4304-4312.

[57]. Shim YY, Gui B, Arnison PG, Wang Y, Reaney MJT (2014) Flaxseed (Linum usitatissimum L.) bioactive compounds and peptide nomenclature: A review. Trends in Food Science \& Technology 38(1): 5-20.

[58]. Czemplik M, Boba A, Kostyn K, Kulma A, Mituła A, et al. (2011) Flax Engineering for Biomedical Application. Biomedical Engineering, Trends, Research and Technologies 644.

[59]. Andruszczak S, Gawlik-Dziki U, Kraska P, Kwiecińska-Poppe E, Różyło K, et al. (2015) Yield and quality traits of two linseed (Linum usitatissimum L.) cultivars as affected by some agronomic factors. Plant Soil Environ 61(6): 247-252.

[60]. Imran M, Ahmad N, Anjum FM, Khan MK, Mushtaq Z, et al. (2015) Potential protective properties of flax lignan secoisolariciresinol diglucoside. Nutrition Journal 14: 71.

[61]. Murray BE, Handyside RJ, Keller WA (1977) In Vitro Regeneration of Shoots on Stem Explants of Haploid and Diploid Flax (Linum Usitatissimum). Canadian Journal of Genetics and Cytology 19(1): 177-186.

[62]. Millam S, Davidson D, Powell W (1992) The use of flax (Linum usitatissimum) as a model system for studies on organogenesis in vitro: the effect of different carbohydrates. Plant Cell, Tissue and Organ Culture 28(2): 163166.

[63]. Bonell ML, Lassaga SL (2002) Genetic analysis of the response of linseed (Linum usitatissimum L.) somatic tissue to in vitro cultivation. Euphytica 125(3): 367-372.

[64]. Millam S, Obert B, Pret'ová A (2005) Plant cell and biotechnology studies in Linum usitatissimum - a review. Plant Cell, Tissue and Organ Culture 82(1): 93-103.

[65]. Bayer OO, Bayer GY, Yemets AI, Blume YaB (2004) In vitro tissue culture establishment and regeneration capacity of fibre flax genotypes with different wind resistance. Physiology and Biochemistry of Cultivated Plants 36(1): 48-54.

[66]. Yildiz M, Özgen M (2006) A comparison of growth regulators for adventitious shoot regeneration from hypocotyls of flax (Linum usitatissimum L.). Food, Agriculture and Environment (JFAE) 4(3\&4): 171-174.

[67]. Gurenko AO, Khytova BM, Klyuchko SV, Vasilenko AN, Brovarets VS (2014) Interaction of 5-chloro-1-phenyl-1H-pyrazole-4-carboxamide and 5-chloro-N-formyl-1-phenyl-1H-pyrazole-4-carboxamide with hydrazine hydrate. J Org Pharm Chem 1(45): 56-59.

[68]. Gurenko AO, Khytova BM, Klyuchko SV, Vasilenko AN, Brovarets VS (2014) Synthesis of novel pyrazolo-[3,4-d]-[1,2,3]-triazines. Chem Het Comp 50(4): 528-536

[69]. Frasinyuk MS, Mrug GP, Bondarenko SP, Sviripa VM, Zhang W, et al (2015) Application of Mannich bases to the synthesis of hydroxymethylated isoflavonoids as potential antineoplastic agents. Org Biomol Chem 13: 11292-11301.

[70]. Mrug GP (2015) Synthesis and properties of new aminomethylisoflavonederivatives. A manuscript. The dissertation for obtaining the Degree of Candidate of Chemical Sciences, speciality 02.00.10 - bioorganic chemistry. Institute of Bioorganic and Petrochemistry, National Academy of Sciense of Ukraine, Kyiv.

[71]. Popovici-Muller J, Salituro FG, Saunders JO, Travinsj, Yan S (2012) Therapeutically Active Compositions And Their Method Of USE Patent: 
WO2012/9678 (A1). Reed Elsevier Properties SA.

[72]. Murashige T, Skoog F (1962) A revised medium for rapid growth and bioassays with tobacco tissue cultures. Physiol Plant 15: 473-497.

[73]. Bang H, Zhou XK, van Epps HL, Mazumdar M (2010) Statistical Methods in Molecular Biology Series: Methods in molecular biology. Humana Press, New York 13(620): 636.

[74]. Blume YaB, Khotyleva LV, Guzenko EV, Bayer OA, Yemets AI, et al. Method of plant rooting in vitro. (RU 2423045).

[75]. Siegién I, Adamczuk A, Wróblewska K (2013) Light affects in vitro organogenesis of Linum usitatissimum L. and its cyanogenic potential. Acta Physiol Plant 35: 781-789.

[76]. Akter F, Parvez MS, Islam MS, Mondol PC, Alam MF (2008) Effects of different hormones on in vitro regeneration of linseed (Linum usitatissimum L.). Plant Environ Dev 2(2): 135-138.

[77]. Rutkowska-Krause I, Mankowska G, Lukaszewicz M, Szopa J (2003) Regeneration of flax (Linum usitatissimum L.) plants from anther culture and somatic tissue with increased resistance to Fusarium oxysporum. Plant Cell Rep 22(2): 110-116.

[78]. Burbulis N, Blinstrubiene A, Venskutoniene E, Katauskyte L (2005) Organogenesis in callus cultures of Linum usitatissimum L. Acta Universitatis Latviensis 691: 129-135.
Special Issue on

"Plant Biology and Genetics"

Edited by:

Victoria Tsygankova,

National Academy of Sciences of Ukraine (NAS of Ukraine), Ukraine

Email :vTsygankova@ukr.net 